\title{
PENGGUNAAN INTERNET DI KALANGAN REMAJA DI JAKARTA
}

\author{
Dudi Iskandar ${ }^{1}$, Muhamad Isnaeni ${ }^{2}$ \\ Fikom Universitas Budi Luhur, Jakarta \\ dudisabiliskandar@yahoo.com ${ }^{1}$, m.isnaeni@yahoo.com²
}

\begin{abstract}
This study aims to determine the use of the internet among teenagers in Jakarta. Using a quantitative approach and the positivism paradigm produces several findings. Among other things, first, respondents generally are very familiar with social media, which is evident from the length of use (more than 2 years). Instagram and Facebook social media are two social media platforms that are most frequently used and accessed by respondents. Second, students use social media not for learning education facilities or seeking information, but as a means of entertainment and finding friends. Third, the majority of respondents updated their social media in a daily period, which consequently had a long frequent duration of social media usage. Based on the results of the hypothesis testing showed no influence between the characteristics of the use of social media with violent behavior in adolescents
\end{abstract}

Key words : internet; teenegers; social media; information

\begin{abstract}
ABSTRAK
Penelitian ini bertujuan untuk mengetahui penggunaan internet di kalangan remaja di Jakarta. Dengan menggunakan paradigma positivisme dan pendekatan kuantitatif, penelitian ini menghasilkan beberapa temuan. Antara lain, pertama, responden umumnya sudah sangat mengenal dengan media sosial, yang terbukti dari lama menggunakan (lebih dari 2 tahun). Media sosial Instagram dan Facebook adalah dua platform media sosial yang paling sering digunakan dan diakses oleh responden. Kedua, para pelajar menggunakan media sosial bukan untuk sarana belajar/pendidikan atau mencari informasi, melainkan sebagai sarana hiburan dan mencari teman. Ketiga, mayoritas responden meng-update media sosialnya dalam jangka waktu harian, yang berkonsekuensi pada durasi penggunaan media sosial dalam jangka waktu satu hari menjadi cukup lama/sering. Berdasarkan Hasil uji hipotesis menunjukkan tidak ada pengaruh antara karakteristik penggunaan media sosial dengan perilaku kekerasan pada remaja
\end{abstract}

Kata kunci : internet; remaja; media sosial; informasi 


\section{PENDAHULUAN}

Sejak kemunculan internet, plus kemudahan mengaksesnya, berbagai aspek kehidupan masyarakat berubah secara drastis dan dramatis. Internet pun sering disebut memunculkan istilah new media dan konvergensi media. Kemunculan media akses yang berbasis internet kian mempertajam efek media. Internet memiliki kemampuan yang belum ada sebelumnya untuk memperkembangkan bentuk baru relasi sosial. Untuk mendeskripsinya adalah melalui kebaruan interaktivitasnya. Karena itu internet benarbenar menjadi sumber individu bebas dan kelompok kecil, dalam dunia egalitarian yang di dalamnya individu tidak dirintangi oleh batasan bangsa, kelas, gender, atau properti (Tony Thwaites dkk, 2009: 330-331). Setelah media cetak dan elektronik menghegemoni masyarakat, dalam beberapa dekade terakhir, internet menjadi biang arus informasi. Masyarakat pun bebas tanpa tekanan mendapatkan dan memproduksi informasi melalui internet.

Meski akurasi informasi pada media akses masih perlu diuji, tetapi dalam ranah kecepatan penyebaran informasi, internet adalah nomor wahid. Kehadiran internet di telepon selular, misalnya, kian mempertegas dominasi kecepatan informasi melalui internet. Selain, kecepatan berita, internet juga menumbuhsuburkan jejaring sosial (facebook, twitter, dan grup-grup yang berlandaskan hobi, profesi, dan kesamaan nasib). Mereka tergabung dalam cybercommunity atau komunitas maya. Singkat kata, internet merupakan media yang mengkonstruksi gerakan massa dan kekuatan civil baru.

Penetrasi penggunaan internet di Indonesia makin tinggi. Data yang dilansir Asosiasi Penyelenggara Jasa Internet Indonesia (APJII) menyebutkan, jumlah pengguna internet di Indonesia mencapai 88,1 juta pengguna pada 2014. Jumlah ini lima kali lebih besar jika dibandingkan tahun 2005 di mana jumlah pengakses internet saat itu hanya sekitar 16 juta orang (Kompas, 21 Juli 2015).

Dengan penetrasi Internet mencapai 35\%, peringkat Indonesia berada di bawah Thailand yang penetrasi internetnya mencapai 37 persen dari total penduduk di negeri tersebut. Sementara itu, Singapura menjadi negara yang daya jangkau penduduknya terhadap akses internet paling baik. Tak kurang dari 81 persen penduduk Singapura sudah terakses internet disusul Malaysia (66 persen), Filipina (44 persen), dan Vietnam (44 persen).

Masalahnya, penggunaan Internet di Indonesia tidak berfokus untuk pencarian informasi. Data menunjukkan, dengan jumlah pengguna aktif internet sekitar 88,1 juta, berbanding lurus dengan jumlah pengguna media sosial saat ini. Berdasarkan data APJII (2015), ada sekitar 79 juta pengguna aktif media sosial di Indonesia. Bila dibandingkan dengan keseluruhan jumlah penduduk, ada sekitar 30 persen penduduk Indonesia yang menjadi pengguna aktif media sosial. 
Di samping pengguna yang terus meningkat, akses internet juga lebih mudah. Para pengguna internet di Indonesia cenderung menggunakan perangkat mobile, dengan jumlah pengguna yang mengakses internet untuk media sosial melalui perangkat mobile ada sekitar 66 juta orang. Salah satu dampak positif internet adalah menjamurnya media sosial. Media ini menjadi tandingan serius bagi media konvensional yang memproduksi jurnalisme. Sebab media sosial saat ini tidak hanya sebagai ajang mencari popularitas tetapi juga sebagai media perlawanan terhadap pemberitaan media konvensional. Lumrah bila saat ini ribuan bahkan jutaan orang memiliki blog, situs pribadi, Twitter, Instalgram, Facebook dan sebagainya.

Fenomena tersebut dapat dipahami, karena penggunaan telepon seluler di Indonesia juga terus meningkat. Hal tersebut sejalan dengan teknologi komunikasi nirkabel yang terus berkembang, mulai dari 1G, 2G, 3G, 4G, dan bahkan 5G yang berbasis GSM, maupun teknologi berbasis CDMA. Berdasarkan data International Telecommunication Union (ITU), pada tahun 2000 jumlah pengguna telepon seluler di Indonesia baru berjumlah 3,6 juta. Angka tersebut melonjak menjadi 280 juta pada 2012 (Ariansyah, 2014:151). Menggunakan basis data jumlah penduduk, diproyeksikan pada 2016, 2017, dan 2018 jumlah pengguna telepon seluler di Indonesia mencapai 389,26 juta; 409,25 juta; dan 426,52 juta (Ariansyah, 2014:165). Perkembangan teknologi seluler serta jumlah penggunanya yang terus bertambah merupakan jawaban atas kebutuhan masyarakat akan akses informasi yang juga terus meningkat dan berkembang.

Menariknya, dari sekitar 88, 1 juta pengguna internet di Indonesia, ternyata kalangan remaja mendominasi. Menurut hasil riset APJII dan Pusat Kajian Komunikasi Universtas Indonesia (UI), mayoritas pengguna internet di Indonesia berada dalam rentang usia 1825 tahun. Jumlah golongan pengguna muda usia ini bahkan hampir setengah (49\%) dari total jumlah pengguna internet di Indonesia.

Remaja yang menggunakan internet dan juga media sosial perlu mendapat perhatian khusus. Hal ini karena potensi tindak kekerasan yang dilakukan oleh remaja akibat terpaan media sosial. Kontrol diri remaja yang masih labil membuat mereka mudah terpengaruh oleh konten yang disajikan oleh media sosial.

Berdasarkan latar belakang yang telah dikemukakan sebelumnya, maka tujuan penelitian ini adalah: (1) Untuk mengetahui karakteristik penggunaan media sosial oleh remaja di Jakarta Selatan. (2) Untuk mengetahui pengaruh penggunaan media sosial tersebut terhadap perilaku kekerasan oleh remaja. 


\section{TINJAUAN PUSTAKA}

\section{Teori Difusi Inovasi}

Perkembangan dan penyerapan teknologi pada satu masyarakat masuk dalam ranah teori Difusi Inovasi. Gambaran tentang hal ini biasanya digambarkan dengan kurva S, M, atau W. Kurva difusi berbentuk S (S-shaped Diffusion Curve). Kurva ini pada dasarnya menggambarkan bagaimana suatu inovasi diadopsi seseorang atau sekolompok orang dilihat dari dimensi waktu.

Adalah Everett M. Rogers tokoh yang mempopulaerkan teori ini dalam komunikasi. dalam karya besarnya Diffusion of Innovation (1961); F. Floyd Shoemaker yang bersama Rogers menulis Communication of Innovation: A Cross Cultural Approach (1971) sampai Lawrence A. Brown yang menulis Innovation Diffusion: A New Perpective (1981).

Difusi Inovasi mengatakan proses suatu inovasi dikomunikasikan melalui saluransaluran tertentu sepanjang waktu kepada sekelompok anggota dari sistem sosial. Difusi merupakan bentuk komunikasi yang bersifat khusus berkaitan dengan penyebaranan pesan-pesan yang berupa gagasan baru.

Ada empat elemen difusi inovasi. Yaitu, Inovasi; gagasan, tindakan, atau barang yang dianggap baru oleh seseorang. Saluran komunikasi; untuk menyampaikan pesan-pesan inovasi dari sumber kepada penerima. Jangka waktu; proses keputusan inovasi, dari mulai seseorang mengetahui sampai memutuskan untuk menerima atau menolaknya, dan terakhir sSistem sosial; kumpulan unit yang berbeda secara fungsional dan terikat dalam kerjasama untuk memecahkan masalah dalam rangka mencapai tujuan bersama Selanjutnya teori difusi inovasi menggambarkan tentang variabel yang berpengaruh terhadap tingkat adopsi suatu inovasi serta tahapan dari proses pengambilan keputusan inovasi. Variabel yang berpengaruh terhadap tahapan difusi inovasi tersebut mencakup atribut inovasi, jenis keputusan inovasi, saluran komunikasi, kondisi sistem sosial, dan peran agen perubah.

Rogers (1995) melanjutkan bahwa tahapan dari proses pengambilan keputusan inovasi mencakup. pertama, tahap munculnya pengetahuan ketika seorang individu (atau unit pengambil keputusan lainnya) diarahkan untuk memahami eksistensi dan keuntungan/manfaat dan bagaimana suatu inovasi berfungsi. Kedua,persuasi ketika seorang individu (atau unit pengambil keputusan lainnya) membentuk sikap baik atau tidak baik. Ketiga, keputusan muncul ketika seorang individu atau unit pengambil keputusan lainnya terlibat dalam aktivitas yang mengarah pada pemilihan adopsi atau penolakan sebuah inovasi. Keempat, implementasi ketika sorang individu atau unit pengambil keputusan lainnya menetapkan penggunaan suatu inovasi. Terakhir, konfirmasi ketika seorang individu atau unit pengambil keputusan lainnya mencari penguatan terhadap keputusan penerimaan atau penolakan inovasi yang sudah dibuat sebelumnya. 


\section{Media Sosial}

Chris Brogan (2010:11) mendefinisikan mendefinisikan media sosial sebagai satu set baru komunikasi dan alat kolaborasi yang memungkinkan banyak jenis interaksi yang sebelumnya tidak tersedia untuk orang biasa. Sedangkan Dailey (2009:3) menyatakan sebagai konten online yang dibuat menggunakan teknologi penerbitan yang mudah diakses dan terukur. Teknologi ini membaca tentang pergeseran cara mengetahui, membaca dan berbagi, serta mencari informasi.

Hadi Purnama (2011:116) memiliki karakteristik Jangkauan: daya jangkauan media sosial dari skala kecil hinga khalayak global; Aksesibilitas: media sosial lebih mudah diakses oleh publik dengan biaya yang terjangkau; Penggunaan: media sosial relatif mudah digunakan karena tidak memerlukan keterampilan dan pelatihan khusus; Aktualitas: media sosial dapat memancing respon khalayak lebih cepat; Tetap: media sosial dapat menggantikan komentar secara instan atau mudah melakukan proses pengeditan.

Menurut Mayfield dalam Muhammad Badri (2011:133) menyebutkan beberapa jenis media sosial. Yakni, jejaring sosial seperti facebook, myspace dan bebo. Situs ini memungkinkan orang untuk membantu halaman web pribadi dan terhubung dengan teman-temannya untuk bebagi konten komunikasi. Blog, merupakan bentuk terbaik dari media sosial, berupa jurnal online dengan pemuatan tulian terbaik, yaitu tulisan terbaru ada di halaman terdepan. Wikis seperti Wikipedia dan ensiklopedia online website. Wikis memperoleh siapa saja utuk mengisi atau mengedit informasi didalamnya, bertindak sebagai sebuah dokumen atau database komunal. Podcasts, menyediakan file-file audio dan video dengan berlangganan melalui layanan seperti Itunes dari Apple. Forum, area untuk diskusi online, seputar topik dan minat tertentu. Forum sudah ada sebelum media sosial dan menjadi komunitas online yang kuat dan populer. Komunitas konten seperti flickr (untuk berbagi foto), del.icio.us (link bookmarked) dan youtube (video). Komunitas ini mengatur dan berbagi jenis konten tertentu. Microblogging, situs jejaring sosial dikombinasikan blog, dimana sejumlah kecil konten (update) didistribusikan secara online dan melalui jaringan mobile phone, twitter adalah pemimpin layanan ini.

\section{METODE PENELITIAN}

Penelitian ini menggunakan paradigma positivisme. menurut Burhan Bungin (2005 : 31), paradigma positivisme memiliki beberapa kriteria. Yakni, (1) Objektif: bebas nilai atau ketika melakukan pengamatan subjek harus benar-benar tidak melibatkan keyakinan gagasan dan lain-lain yang ia miliki. (2) Fenomenalisme: apa yang kita amati merupakan gejala fenomena semata. (3) Reduksionalisme: menyederhanakan kenyataan bisa jadi fakta-fakta yang dapat dipersepsi. (4) Naturalisme: semua gejala berjalan secara alamiah tanpa campur tangan hal-hal metafisis. (5) Nomiralisme: hanya ada didalam persepsi 
individu semata yang tersusun tidak lebih dari sekedar nama, label, dan lain-lain, yang digunakan untuk membangun sebuah realitas. (6) Mekanisme: semua gejala dapat dilakukan secara mekanis.

Dengan demikian alasan peneliti memakai paradigma positivisme karena dalam penelitian ini ingin mengetahui yang bersifat kausalitas. Yaitu, bagaimana suatu gejala sosial digeneralisasikan dan mempunyai hubungan kausal. Dalam konteks penelitan ini, unsur sebab akibat yang ingin diketahui adalah hubungan pemahaman agama dan produksi jurnalistik islami.

Pendekatan dalam penelitian ini merupakan pendekatan kuantitatif. Manasse Malo (1986 : 39) menyatakan penelitian kuantitatif mengetengahkan asumsi dan hipotesis masalah yang didukung oleh tinjauan pustaka. Beberapa pertimbangan pengambilan metode kuantitatif ini adalah pertama, menggunakan desain atau rencana yang spesifik, terukur, dan jelas serta ditentukan sebelum penelitian dilakukan. Kedua, bertujuan melihat hubungan antarvariabel. Ketiga, teknik pengumpulan data menggunakan kuesioner yang diajukan kepada responden dalam bentuk angket.

Metode penelitian yang dipakai adalah survei yang meneliti dan mengambil sampel dalam satu populasi. Metode Survei kata Kerlinger (1997) seperti dikutip Sugiyono (2001 : 16) menyatakan penelitian yang dilakukan dalam populasi besar atau kecil. Juwono Tri Atmodjo (2011 : 19) menambahkan, penelitian survei adalah suatu penelitian yang mengambil sampel dari suatu populasi dan menggunakan kuisioner sebagai alat pengumpul data yang pokok, lazimnya dengan menguji hipotesis. Metode survei sambung Mohamad Nazir (1983 : 65) menjelaskan bahwa metode survei membedah dan menguliti serta masalah-masalah serta pembenaran terhadap keadaaan dan praktikpraktik yang sedang berlangsung. Data yang dikumpulkan dan dipelajari adalah data sampel dari populasi tersebut. Dari data sampel setelah diberi kuesioner akan diketahui hubungan kausalitas antara variabel bebas dan variabel terikat.

\section{HASIL DAN PEMBAHASAN}

\section{Populasi dan Sampel Penelitian}

Penelitian tahap pertama ini dilakukan di Jakarta Selatan.Berdasarkan data Dinas Pendidikan DKI Jakarta (2017), jumlah siswa SMA di Jakarta Selatan adalah 37.634 siswa, terdiri atas 22.679 siswa SMA negeri, dan 14.955 siswa SMA swasta. Karena populasi jumlah siswa SMA tersebut cukup besar, maka sampel yang akan diteliti sebagai responden ditentukan dengan menggunakan rumus Yamane (Kriyantono, 2009), yakni:

dengan:

$$
\mathrm{n}=\frac{N}{N d^{2}+1}
$$

$\mathrm{n} \quad=$ ukuran sampel 


\begin{abstract}
$\mathrm{N} \quad=$ ukuran populasi
d =kelonggaran ketidaktelitian karena kesalahan pengambilan sampel, dalam penelitian ini adalah $10 \%$.
\end{abstract}

Setelah dihitung dengan rumus Yamane tersebut, maka sampel dalam penelitian ini adalah 100 siswa (dibulatkan).Karena populasi pelajar SMA cenderung homogen, maka pengambilan sampel dilakukan dengan metode simple random sampling. Adapun teknik penarikan sampel untuk penelitian ini disajikan di gambar berikut:

\title{
Gambar 4.1. Diagram alir penarikan sampel
}

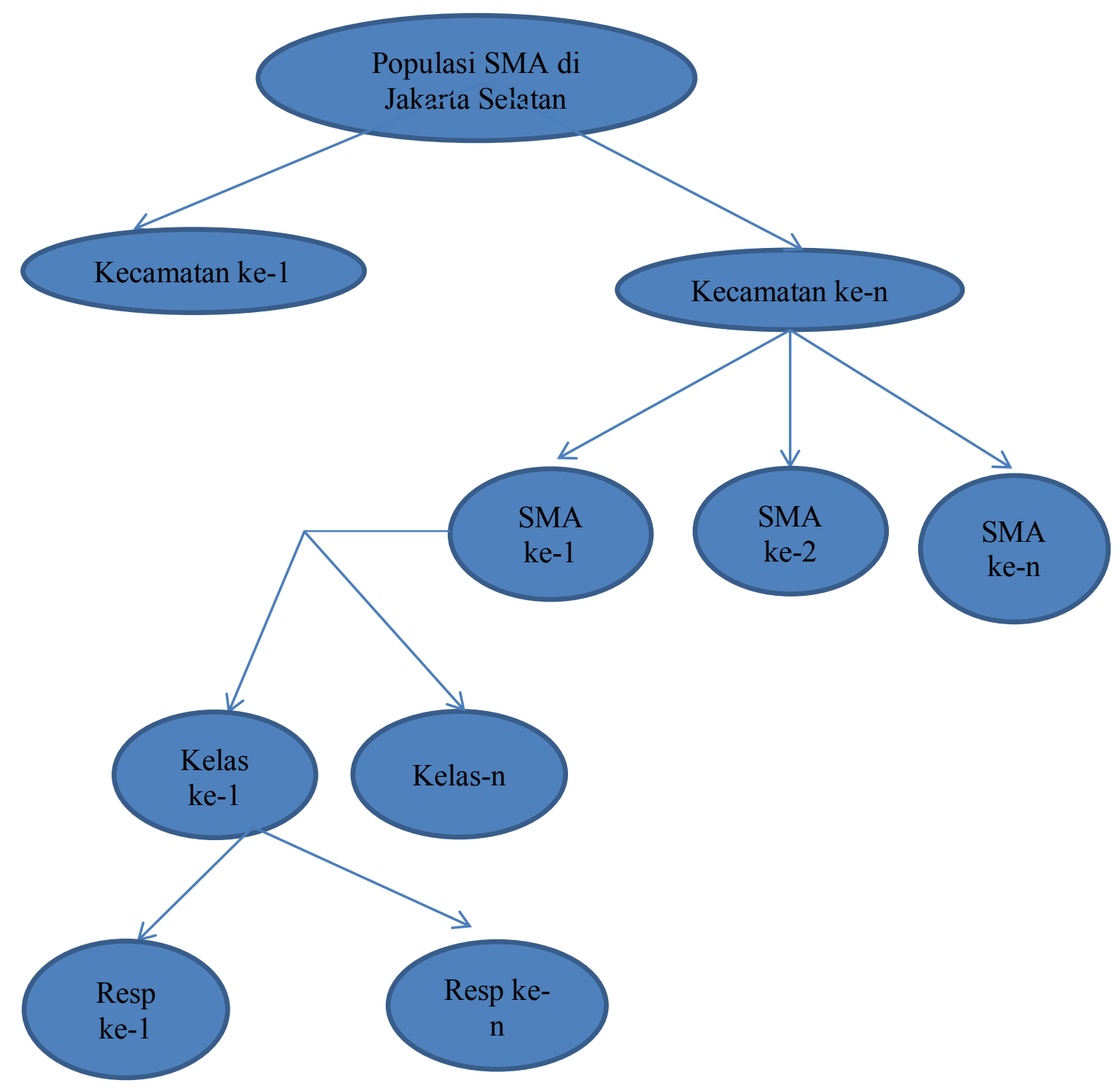




\section{Karakteristik Responden}

Hasil penelitian menunjukkan, sebanyak 67 responden (67\%) berjenis kelamin laki-laki, sedangkan 33 responden (33\%) berjenis kelamin perempuan. Dari sisi usia, sebanyak 43 responden (43\%) berusia 16 tahun, 38 responden berusia 17 tahun (38\%), dan 19 responden berusia 18 tahun (19\%). Dari sisi kepemilikan perangkat untuk mengakses Internet, sebanyak 63 responden memiliki telepon pintar (smartphone) dan komputer jinjing (laptop) sekaligus, sementara 37 responden hanya memiliki smartphone saja. Untuk akses internet, sebanyak 81 responden mengakses melalui smartphone, dan hanya 19 responden yang mengakses melalui laptop atau desktop.

Sebagian besar responden, yakni 84 responden mengakses Internet dari rumah (84\%), sebanyak 9 responden mengakses dari sekolah (9\%) dan 7 responden mengakses dari warung Internet (7\%). Untuk media sosial yang sering digunakan, sebanyak 37 responden menggunakan Instagram (37\%), sebanyak 32 responden menggunakan Facebook (32\%), sebanyak 15 responden menggunakan WhatsApp (15\%), sebanyak 6 responden menggunakan Twitter (6\%), sebanyak 6 responden menggunakan Line (6\%), dan sisanya (4 responden) menggunakan media sosial lain (4\%).

Untuk lama penggunaan, sebanyak 85 reponden sudah 2 tahun atau lebih menggunakan media sosial (85\%), sebanyak 12 responden selama 1 tahun (12\%), dan sebanyak 3 responden kurang dari satu tahun (3\%). Adapun tujuan penggunaan media sosial, sebanyak 79 responden menggunakannya untuk mencari teman (79\%), sebanyak 10 responden untuk hiburan (10\%), sebanyak 7 responden untuk bisnis/berdagang online (7\%), dan 4 responden untuk keperluan lain-lain (4\%).

Dari sisi update media sosial, sebanyak 84 responden meng-update secara harian (88\%), sebanyak 9 responden meng-update secara mingguan (9\%), dan 7 responden mengupdate secara bulanan (7\%). Untuk pengeluaran bagi keperluan mengakses media sosial dalam satu bulan, sebanyak 51 responden mengeluarkan antara Rp. 100 ribu-Rp. 150 ribu (51\%), sebanyak 42 responden mengeluarkan antara Rp. 50 ribu-Rp. 75 ribu (42\%), dan hanya 7 responden yang mengluarkan kurang dari Rp. 50 ribu (7\%).

Tabel 4.1. Karakteristik Responden

\begin{tabular}{llll}
\hline No & Karakteristik & & Jumlah (\%) \\
\hline \multirow{2}{*}{1} & Jenis Kelamin & Laki-laki & $67(67 \%)$ \\
\cline { 3 - 4 } & & Perempuan & $33(33 \%)$ \\
\hline 2 & Usia & 16 Tahun & $43(43 \%)$ \\
\cline { 3 - 4 } & & 17 Tahun & $38(38 \%)$ \\
\cline { 3 - 4 } & & 18 Tahun & $19(19 \%)$ \\
\hline \multirow{2}{*}{3} & Kepemilikan & Smartphone & $37(37 \%)$ \\
\cline { 3 - 4 } & perangkat & Laptop & $63(0 \%)$ \\
\cline { 3 - 4 } & & Smartphone dan laptop & $63(63 \%)$ \\
\hline
\end{tabular}




\begin{tabular}{|c|c|c|c|}
\hline \multirow[t]{2}{*}{4} & \multirow{2}{*}{$\begin{array}{l}\text { Perangkat untuk } \\
\text { mengakses }\end{array}$} & Smartphone & $81(81 \%)$ \\
\hline & & Laptop & $19(19 \%)$ \\
\hline \multirow[t]{3}{*}{5} & \multirow{3}{*}{$\begin{array}{l}\text { Lokasi } \\
\text { mengakses } \\
\text { internet }\end{array}$} & Sekolah & $9(9 \%)$ \\
\hline & & Rumah & $84(84 \%)$ \\
\hline & & Warung Internet & $7(7 \%)$ \\
\hline \multirow[t]{6}{*}{6} & \multirow{6}{*}{$\begin{array}{l}\text { Media sosial } \\
\text { yang sering } \\
\text { digunakan }\end{array}$} & Instagram & $37(37 \%)$ \\
\hline & & Facebook & $32(32 \%)$ \\
\hline & & Twitter & $6(6 \%)$ \\
\hline & & Line & $6(6 \%)$ \\
\hline & & WhatsApp & $15(15 \%)$ \\
\hline & & Lainnya & $4(4 \%)$ \\
\hline \multirow[t]{3}{*}{7} & \multirow{3}{*}{$\begin{array}{l}\text { Lama } \\
\text { menggunakan }\end{array}$} & 2 tahun atau lebih & $85(85 \%)$ \\
\hline & & 1 tahun & $12(12 \%)$ \\
\hline & & Kurang dari 1 tahun & $3(3 \%)$ \\
\hline \multirow[t]{4}{*}{8} & \multirow{4}{*}{$\begin{array}{l}\text { Tujuan } \\
\text { penggunaan }\end{array}$} & Mencari teman & $79(79 \%)$ \\
\hline & & Hiburan & $10(10 \%)$ \\
\hline & & Bisnis & $7(7 \%)$ \\
\hline & & Lain-lain & $4(4 \%)$ \\
\hline \multirow[t]{3}{*}{9} & \multirow[t]{3}{*}{ Waktu update } & Harian & $84(84 \%)$ \\
\hline & & Mingguan & $9(9 \%)$ \\
\hline & & Bulanan & $7(7 \%)$ \\
\hline \multirow[t]{3}{*}{10} & \multirow{3}{*}{$\begin{array}{l}\text { Pengeluaran } \\
\text { untuk keperluan } \\
\text { media sosial }\end{array}$} & Rp. 100.000-Rp.150.000 & $51(51 \%)$ \\
\hline & & Rp. 50.000-Rp. 75.000 & $42(42 \%)$ \\
\hline & & Kurang dari Rp. 50.000 & $7(7 \%)$ \\
\hline
\end{tabular}

\section{Karakteristik Penggunaan Media Sosial}

Indikator untuk mengukur variabel karakteristik pengunaan media sosial antara lain: durasi penggunaan, yakni untuk mengukur lamanya responden menggunakan media sosial yaitu : $\geq 7$ Jam: Sangat lama, 5-6 Jam : Lama, 3-4 Jam : Sedang, 1-2 Jam : Singkat, dan $<1$ jam : sangat singkat. Indikator lainnya adalah aktivitas bersosial media, yakni: up load foto, up date status, melihat profil, news feed, dan berkomentar. Kemudian interaksi teman pada media sosial, yakni: keluarga, teman sekolah, teman main, dan orang tidak dikenal.

Karakteristik tersebut kemudian dioperasionalisasi, sehingga menghasilkan 14 item butir pertanyaan, yakni: durasi penggunaan sebanyak 3 pertanyaan, aktivitas bersosial media 7 pertanyaan, dan interaksi 4 pertanyaan. Untuk memudahkan dalam interpretasi, maka dibuat interpretasi pembobotan. Caranya dengan menghitung nilai tertinggi $(\mathrm{X})$ dan nilai terendah (Y) untuk item penilaian dengan rumus berikut ini:

$\mathrm{X}=$ Skor tertinggi likert $\mathrm{x}$ jumlah responden

$\mathrm{Y}=$ Skor terendah likert $\mathrm{x}$ jumlah responden 
Dengan demikian, X adalah 400, dan Y adalah 100. Penilaian interpretasi responden terhadap butir pertanyaan kuesioner adalah hasil nilai yang dihasilkan dengan menggunakan rumus Index \%.

$$
\text { Rumus Index \% = (Total Skor } / \mathrm{X}) \times 100
$$

Karena penelitian ini menggunakan skala likert, maka dibuat juga kategori penilaian berdasarkan besarnya skala yang digunakan. Berikut kriteria interpretasi skornya berdasarkan dari interval terendah $0 \%$ hingga tertinggi $100 \%$

Tabel 4.2 Persentase Nilai

\begin{tabular}{ll}
\hline Jawaban & Keterangan \\
\hline $0 \%-24.99 \%$ & Sangat Tidak Setuju, Buruk atau Kurang Sekali \\
\hline $25 \%-49.99 \%$ & Tidak Setuju atau Kurang Baik \\
\hline $50 \%-74,99 \%$ & Setuju,/Baik/Suka/Moderat \\
\hline $75 \%-100 \%$ & Sangat (Setuju, Baik, Suka) \\
\hline
\end{tabular}

\section{Aspek Durasi}

Angket untuk aspek durasi terdiri atas 3 butir pertanyaan. Hasil untuk interpretasi pembobotan disajikan di tabel 4.3 berikut ini:

\section{Tabel 4.3 Aspek Durasi}

\begin{tabular}{lll}
\hline Pertanyaan & Skor & Bobot (\%) \\
\hline XA1 & 310 & 77.5 \\
\hline XA2 & 260 & 65 \\
\hline XA3 & 300 & 75 \\
\hline Rerata & & 72.5
\end{tabular}

Dengan rata-rata bobot 72.5 , maka dapat dikatakan bahwa durasi penggunaan media sosial responden berada pada level moderat.

\section{Aspek Aktivitas}

Angket untuk aspek durasi terdiri atas 7 butir pertanyaan. Hasil untuk interpretasi pembobotan disajikan di tabel 4.4 berikut ini:

\section{Tabel 4.4 Aspek Aktivitas}

\begin{tabular}{lll}
\hline Pertanyaan & Skor & Bobot (\%) \\
\hline $\mathrm{X} 4$ & 270 & 67.5 \\
\hline $\mathrm{X} 5$ & 340 & 85 \\
\hline $\mathrm{X} 6$ & 160 & 40 \\
\hline $\mathrm{X} 7$ & 300 & 75 \\
\hline $\mathrm{X} 8$ & 280 & 70 \\
\hline $\mathrm{X} 9$ & 310 & 77.5 \\
\hline X10 & 260 & 65 \\
\hline Rerata & & 68.57 \\
\hline
\end{tabular}


Dengan rata-rata bobot 68.57, maka dapat dikatakan bahwa aktivitas penggunaan media sosial responden berada pada level baik/moderat.

Aspek Interaksi

Angket untuk aspek interaksi terdiri atas 4 butir pertanyaan. Hasil untuk interpretasi pembobotan disajikan di tabel 4.5 berikut ini:

Tabel 4.5 Aspek Interaksi

\begin{tabular}{lll}
\hline Pertanyaan & Skor & Bobot (\%) \\
\hline $\mathrm{X} 11$ & 250 & 62,5 \\
\hline $\mathrm{X} 12$ & 270 & 67,5 \\
\hline $\mathrm{X} 13$ & 310 & 77,5 \\
\hline $\mathrm{X} 14$ & 330 & 82,5 \\
\hline Rerata & & $\mathbf{7 2 , 5}$ \\
\hline
\end{tabular}

Karena nilai bobot mempunyai skor 72,5 maka dapat dikatakan bahwa responden memiliki karakteristik yang baik terkait dengan interaksi dalam bermedia sosial.

\section{Perilaku Kekerasan oleh Remaja}

Untuk variabel kekerasan pada remaja, indikatornya adalah kekerasan verbal dan kekerasan fisik.Hasil untuk interpretasi pembobotan disajikan di tabel 4.6 berikut ini:

\begin{tabular}{lll}
\hline Pertanyaan & Skor & Bobot (\%) \\
\hline Y1 & 210 & 52.5 \\
\hline Y2 & 210 & 52.5 \\
\hline Y3 & 250 & 62.5 \\
\hline Y4 & 190 & 47.5 \\
\hline Y5 & 160 & 40 \\
\hline Y6 & 220 & 55 \\
\hline Rerata & & $\mathbf{5 1 . 6}$ \\
\hline
\end{tabular}

Karena nilai bobot mempunyai skor 51.6 maka dapat dikatakan bahwa responden terkait dengan perilaku kekerasan, cukup memenuhi unsur verbal dan fisik.

\section{Pengaruh Karakteristik Penggunaan Media Sosial Terhadap Perilaku Kekerasan}

Rumusan hipotesis penelitian ini disarikan dalam tabel berikut:

\begin{tabular}{|c|c|}
\hline Hipotesis Penelitian & Hipotesis Statistik \\
\hline $\begin{array}{lr}\text { Terdapat } & \text { pengaruh } \\
\text { antara } & \text { karakteristik }\end{array}$ & $\begin{array}{l}\text { Ho: Tidak terdapat pengaruh antara karakteristik } \\
\text { penggunaan media sosial dengan perilaku kekerasan }\end{array}$ \\
\hline $\begin{array}{l}\text { penggunaan media } \\
\text { sosial dengan perilaku } \\
\text { kekerasan }\end{array}$ & $\begin{array}{l}\text { Ha: } \quad \text { Terdapat pengaruh antara karakteristik } \\
\text { penggunaan media sosial dengan perilaku kekerasan }\end{array}$ \\
\hline
\end{tabular}


Karena penelitian ini menggunakan data ordinal, maka uji statistiknya memakai uji Chi square. Adapun hasil pengujian hipotesis adalah:

Tabel 4.19

Hasil Uji Hipotesis

\begin{tabular}{|l|l|l|l|}
\hline & Value & $\mathrm{df}$ & $\begin{array}{l}\text { Asymptotic } \\
\text { Significance } \\
\text { (2-sided) }\end{array}$ \\
\hline Pearson Chi-Square & $52.500^{\mathrm{a}}$ & 42 & 147 \\
Likelihood Ratio & 33.915 & 42 & 808 \\
Linear-by-Linear & 1.010 & 1 & 315 \\
Association & 100 & & \\
N of Valid Cases & 1.00 & \\
\hline
\end{tabular}

a. 56 cells (100.0\%) have expected count less than 5 . The minimum expected count is .10 .

Berdasarkan panduan SPSS, untuk mengambil keputusan dari tabel di atas, dapat digunakan dengan melihat significance (Sig) (a) Bila nilai sig $<0.05$, maka ada korelasi yang signifikan (Ha diterima) (b) Bila nilai sig $>0.05$, maka tidak ada korelasi yang signifikan (Ho diterima) Karena nilai signifikansi $>0.05$, dapat dikatakan bahwa $\mathrm{H}_{0}$ diterima. Dengan demikian, tidak terdapat pengaruh antara karakteristik penggunaan media sosial dengan perilaku kekerasan.

\section{Pembahasan}

Penelitian berupaya menangkap fenomena sosial di balik maraknya tindakan kekerasan, misalnya cyberbullying, atau kekerasan yang dilakukan secara fisik yang dilakukan oleh remaja.Penggunaan media sosial yang diluar kontrol ditengarai menjadi salah satu penyebab dari meningkatnya tindak kekerasan tersebut.

Hasil penelitian ini menunjukkan bahwa Instagram dan Facebook adalah dua media sosial yang paling sering diakses oleh remaja. Hal ini bersesuaian dengan pandangan $\mathrm{Hu}$, Manikonda, dan Kambhampati (2014) yang menyatakan bahwa Instagram merupakan platform media sosial yang paling cepat perkembangnnya disbanding media sosial lain. Hal ini menjadikan Instagram sebagai media sosial yang digemari, karena memberikan kemudahan pada penggunanya untuk secara cepat/instan mengkap dan membagian momen kehidupan mereka melalui sejumlah foto dan video. Meskipun demikian, penelitian ini belum berhasil mengungkap lebih dalam bagaimana karakteristik penggunaan Instagram oleh remaja serta bagaimana pengaruhnya terhadap perilaku kekerasan.

Facebok adalah media sosial kedua yang paling banyak digunakan. Withall (Sheldon 2008) mengemukakan bahwa remaja menjadikan facebook sebagai Social Bible atau 
pedoman dalamkehidupan sosial yang penting untuk mencari informasi dan berhubungandengan teman, orang yang ditaksir, teman yang sudah lama mereka tidaktemui, hingga yang baru mereka kenal.Remaja yang mengakrabkan diridengan teman-teman yang sudah dikenal serta mencari teman yangbelum dikenal dalam waktu bersamaan menyebabkan remaja menjadi sangat riskan.

Menurut Berson, Berson, dan Ferron (2002), remaja sangat mudah untuk mendapatkan interaksi sosial yangnegatif apalagi seiring denganpemakaian internet yang rutin-bahkanberlebihan kedalam bentuk-bentukviktimisasi dalam dunia maya sepertibullying (pengucilan, atau perlakuankasar pada remaja dilakukan olehremaja lainnya), harrasment (perlakuankasar yang dilakukan siapa saja, dandapat berupa kekerasan fisik ataupunpsikis) dan sexual solicitation/ajakan-ajakan untuk melakukan hal yangmengarah pada perbuatan seksual. Hal senada juga dikemukakan oleh Juvonen dan Gross (2008) yang mengemukakan bahwa berkembangnya penggunaan teknologi komunikasikhususnya pada remaja, dunia maya menjadi wadah baru yang beresiko bagi aksi kekerasan. Efek negatif dalam berinternet yang akhirnya menimbulkan perilaku kekerasan pada dunia maya disebut dengan cyberbullying.

Hasil penelitian ini juga mengungkap bahwa durasi penggunaan media sosial tertinggi terjadi pada level harian, yakni dengan meng-update apapun yang terjadi dengan media sosial. Hal ini tentu menguatirkan, karena responden ternyata lebih banyak menghabiskan waktunya untuk bersosial media daripada belajar.Di samping itu, mereka juga menggunakan sosial media hanya untuk mencari teman dan hiburan.Tidak ada responden yang menggunakan media sosial untuk pendidikan atau mencari informasi. Indikator durasi dalam penelitian ini menjadi kesulitan tersendiri, karena penelitian ini tidak secara khusus mengamati durasi siswa ketika menggunakan media sosial, dan hal ini menjadi bias ketika pertanyaan-pertanyaan tersebut dijawab oleh responden, apakah memang responden menjawab yang sebenarnya atau hanyakan sekadar mengisi angket saja.

Hasil penelitian ini juga menyimpulkan tidak ada pengaruh dari karakteristik penggunaan media sosial (durasi, aktivitas, dan interaksi) terhadap perilaku kekerasan oleh remaja.Hal ini menunjukkan masih adanya indicator-indikator yang belum dapat terfasilitasi oleh instrumen penelitian.

Keterbatasanlaindari penelitian ini adalah fakta bahwa pelajar pertama kali ditanya apakah mereka telah terlibat dalam kekerasan atau telah menjadi korban kekerasan dan bukan untuk menunjukkan sifat dari penggunaan media sosial terhadap kekerasan itu sendiri. Dapat dibayangkan bahwa apa yang dimaksudkan sebagai kekerasan dianggap oleh beberapa siswa sebagai hal yang menarik, meskipun hasil penelitian dan operasionalisasi yang disajikan mengenai kekerasan dalam kuesioner masih mengambang. Hal ini berimplikasi bahwa persentase pelaku kekerasan dan korban dapat dikecualikan.Selain itu, responden mungkin memberikan jawaban yang diinginkan 
secara sosial atas pertanyaan tentang kekerasan.Hal ini karena remaja masih dalam proses pencarian jatidiri, yang secara sosial dipengaruhi oleh norma kelompok bahwa kekerasan tidak boleh dilakukan atau oleh norma kelompok bahwa kekerasan justru keren, yang membuat distorsi dalam pengisian kuesioner.

\section{SIMPULAN}

Berdasarkan penelitian yang telah dilakukan, maka dapat ditarik kesimpulan. Pertama, responden umumnya sudah sangat mengenal dengan media sosial, yang terbukti dari lama menggunakan (lebih dari 2 tahun). Media sosial Instagram dan Facebook adalah dua platform media sosial yang paling sering digunakan dan diakses oleh responden. Para pelajar menggunakan media sosial bukan untuk sarana belajar/pendidikan atau mencari informasi, melainkan sebagai sarana hiburan dan mencari teman. Selain itu, mayoritas responden meng-update media sosialnya dalam jangka waktu harian, yang berkonsekuensi pada durasi penggunaan media sosial dalam jangka waktu satu hari menjadi cukup lama/sering. Kedua, hasil uji hipotesis menunjukkan tidak ada pengaruh antara karakteristik penggunaan media sosial dengan perilaku kekerasan pada remaja.

\section{DAFTAR PUSTAKA}

Ariansyah, K. (2014). Proyeksi Jumlah Pelanggan Telepon Bergerak Seluler di Indonesia. Buletin Pos dan Telekomunikasi, 12(2), 151-166.

Badan Pusat Statistik Jakarta. (2014) Indeks Potensi Kerawanan Sosial. Jakarta:Badan Pusat Statistik Jakarta.

Badri, M., (2011). Corporate and Marketing Communication. Jakarta: Universitas Mercu Buana.

Bungin, B., (2005). Metodologi Penelitian Kuantitatif Edisi Pertama, Jakarta: Kencana Prenada Media Group.

Berson, I. R., Berson, M. J., \& Ferron, J. M. (2002). Emerging risks of violence in the digital age: Lessons for educators from an online study of adolescent girls in the United States.Journal ofSchool Violence,1(2):51-71

Capra, F., (2001). The Web of Life; A New Synthesis of Mind and Matter, penerjemah Saut Pasaribu. Yogyakarta. Fajar Pustaka Baru. 
Ekasari, P., \& Dharmawan, A. H. (2012). Dampak sosial-ekonomi masuknya pengaruh internet dalam kehidupan remaja di pedesaan. Departemen Sains Komunikasi dan Pengembangan Masyarakat, Fakultas Ekologi Manusia, IPB.

M Rogers, E. (1962). Diffusion of innovations. Collier Macmilan, News York.

Gulo, W., (2007). Teknik Pengolahan dan Interpretasi Data, Jurusan Pendidikan Ilmu Pengetahuan Sosial, Universitas Haluoleo.

Hamidi, (2010). Metode Penelitian dan Teori Komunikasi, UMM Press, Malang.

Hu, Y., Manikonda, L., \& Kambhampati, S. (2014). What we instagram: afirstanalysis of instagram photo content and user types. InProceedings of AAAI International Conference on Web and Social Media

Umar, H. (2002). Riset pemasaran dan perilaku konsumen. Jakarta: PT Gramedia Pustaka Utama.

Juvonen, Jaana \& Elisheva F. Gross. (2008). Extending the School Grounds?-Bullying Experiences in Cyberspace. Ournal of School Health 78 (9): 496-505. https://doi.org/10.1111/j.1746-1561.2008.00335.x

Juwono, Kusumo, T., (2011). Modul kuliah Metode Penelitian Komunikasi , Magister Komunikasi Fakultas Ilmu Komunikasi Universitas Mercu Buana, Jakarta.

Kuhn, T. S. (2012). The structure of scientific revolutions. University of Chicago press.

Kuntowijoyo. (1991). Paradigma Islam: interpretasi untuk aksi. Mizan.

Malo, M. (1986). Metode penelitian sosial. Penerbit Karunika, Jakarta.

Nazir, M. (2001). Metode Penelitian Bisnis. Bandung. Alfa Beta.

Pawito, (1983). Metode Penelitian, Balai Aksara, Jakarta.

Purnama, Hadi. (2011). Media Sosial Di Era Pemasaran 3.0. Corporate and Marketing Communication. Jakarta : Pusat Studi Komunikasi dan Bisnis Program Pasca Sarjana Universitas Mercu Buana

Sheldon, P., (2008). The Relationship BetweenUnwillingness-to-Communicateand Students' Facebook Use. Journal of Media Psychology 2008; Vol. 20(2):67-75. https://doi.org/10.1027/1864-1105.20.2.67

Widiantari, S., Komang dan Hediyanto, Y. Kartika, (2013). Perbedaan Intensitas Komunikasi Melalui Jejaring Sosial antara Tipe Kepribadian Ekstrovert dan Introvert pada Remaja, Jurnal Psikologi Udayana Vol. 1, No. 1. 
Sugiyono, (2006). Penelitian Kualitatif, Kuantitatif, dan R\&D, Alfabeta, Bandung.

Thwaites, T., Davis, L., \& Mules, W. (2009). Introducing Cultural And Media Studies, Sebuah Pendekatan Semiotik. Yogyakarta: Jalasutra. 